\title{
Biocompatibility Problem Identified
}

National Cancer Institute

\section{Source}

National Cancer Institute. Biocompatibility Problem Identified. NCI Thesaurus. Code C92029.

The device causes cellular or tissue responses that elicit an undesirable local or systemic effect in the recipient or beneficiary of that therapy. (See ISO 10993) 